\begin{tabular}{|c|c|c|}
\hline 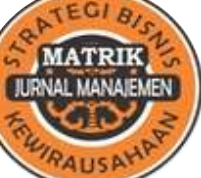 & $\begin{array}{l}\text { MATRIK: JURNAL MANAJEMEN, STRATEGI BISNIS } \\
\text { DAN KEWIRAUSAHAAN } \\
\text { Homepage: } \underline{\text { https://ojs.unud.ac.id/index.php/imbk/index }}\end{array}$ & 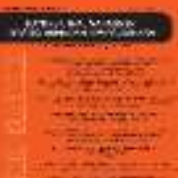 \\
\hline $\begin{array}{l}\text { P-ISSN: } 1978-2853 \\
\text { E-ISSN: } 2302-8890\end{array}$ & Vol. 15 No. 2, Agustus (2021), 243-252 & \\
\hline
\end{tabular}

\title{
Generasi Z di Bali: Lifestyle dan Social Media Influencer Mengubah Smoker Menjadi Vapor
}

\author{
I Wayan Gede Antok Setiawan Jodi 1)*, Bagus Nyoman Kusuma Putra ${ }^{2)}$, \\ I Made Surya Prayoga ${ }^{3)}$, Tiksnayana Vipraprastha ${ }^{4}$ \\ 1,2,3,4 Fakultas Ekonomi dan Bisnis, Universitas Mahasaraswati Denpasar \\ email: Gedejodi@unmas.ac.id
}

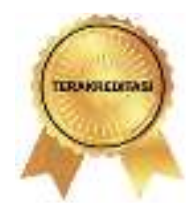

SINTA 2

\section{DOI : https://doi.org/10.24843/MATRIK:JMBK.2021.v15.i02.p07}

\begin{abstract}
ABSTRAK
Upaya pemasaran untuk menarik purchase intention adalah dengan memperhatikan lifestyle di masyarakat disertai dengan adanya social media influencer. Dengan semakin meningkatnya purchase intention terutama yang ditujukan pada generasi $\mathrm{Z}$ yang berusia 17-25 tahun, penelitian ini bertujuan untuk mencari tahu hubungan lifestyle dan social media influencer terhadap purchase intention. Penelitian ini melibatkan 110 responden di Bali. Ada dua hipotesis yang dikemukakan untuk dianalisis secara mendalam. Terdapat perbedaan pada studi sebelumnya, hasil menyatakan bahwa adanya hubungan antara lifestyle dan social media influencer terhadap purchase intention. Dalam penelitian ini memberikan sejumlah implikasi, batasan dan arahan untuk penelitian selanjutnya.
\end{abstract}

Kata kunci: lifestyle, social media influencer, purchase intention

\section{Z Generation in Bali: Lifestyle and Social Media Influencers Turn Smoker into Vapor}

\begin{abstract}
The marketing effort to attract purchase intention is to pay attention to the lifestyle in the community accompanied by social media influencers. With the increasing increase in purchase intention, especially those aimed at generation $Z$ aged 17-25 years, this study aims to find out the relationship between lifestyle and social media influencers on purchase intention. This study involved 110 respondents in Bali. There are two hypotheses put forward for in-depth analysis. There are differences in previous studies, the results state that there is a relationship between lifestyle and social media influencers on purchase intention. This research provides a number of implications, limitations and directions for further research
\end{abstract}

Keyword: lifestyle, social media influencer, purchase intention

\section{PENDAHULUAN}

Di dunia ini merokok adalah faktor penyebab sebagian meninggalnya manusia serta dengan perkiraan jumlah lima juta orang setiap tahunnya (Brown et al., 2014). Dalam mencegah penyakit dan kematian yang di sebabkan oleh rokok, terdapat sejumlah alternatif solusi seperti tembakau tanpa asap dan system pengiriman nikotin yang merupakan suatu metode yang paling populer yaitu rokok elektrik (Cho et al., 2011). Rokok elektrik (e-rokok) merupakan perangkat bertenaga baterai dengan memberikan nikotin yang diuapkan, yang terdapat di gliserol (Goniewicz et al., 2013). Salah satu riset dilaksanakan di 7 wilayah, yaitu 
Jerman, Russia, Inggris, Polandia, Prancis, Korea Selatan, dan Italia menunjukkan kenaikan mendekati dua kali lipat sejak 2013 ke tahun 2015 sejumlah 0,9\% menjadi 1,7\% (Eichler et al., 2016). Kebiasaan merokok sudah menjadi hal yang umum di masyarakat. Walaupun para perokok sadar akan dampak buruk bagi kesehatan namun tidak semua orang peduli akan hal tersebut. Berbeda halnya dengan generasi Z, karakteristik generasi Z yang menyukai hal-hal baru serta dengan kemampuannya dalam mengakses informasi baru berusaha mencari alternatif untuk mengurangi resiko kesehatan pada kebiasan merokok. Sehingga vape dijadikan sebagai salah satu alternatif penganti rokok pada generasi Z. Perilaku generasi Z dalam mengakses internet membuatnya mudah terpengaruh oleh influencer di social media. Rasa ingin tahu yang tinggi membuat generasi $\mathrm{Z}$ cenderung selalu berupaya merasakan hal yang baru salah satunya menggunakan vape hal ini diperkuat dengan anggapan yang cenderung menyatakan bahwa penggunakan vape memiliki resiko kesehatan yang lebih kecil.

Beberapa hasil riset terdahulu menyebutkan bahwa pemakaian rokok elektrik cenderung digunakan oleh generasi muda (usia 15 sampai dengan 24 tahun) dimana beberapa peneliti menyatakan rokok elektrik cenderung di gunakan oleh anak muda hingga dewasa dengan usia 15 sampai dengan 39 tahun (Simon et al., 2019) \& (Vardavas et al., 2014). Namun, salah satu studi yang dilakukan di Jerman, sebagian besar generasi muda memakai rokok elektrik karena resiko rokok elektrik cenderung lebih rendah jika ibandingkan dengan rokok tembakau, sebagian orang berusia dewasa dan berumur menyatakan bahwa baik rokok elektrik dengan rokok tembakau mempunyai bahaya yang sama (Eichler et al., 2016). Pendapat lain dari generasi muda disebabkan desain rokok elektrik yang khusus, memiliki beragam varian, dan daya energi dengan menggunakan USB yang mudah diaplikasikan (H. Lee et al., 2016). Berbeda dengan studi lainnya yang menyatakan bahwa rokok elektrik mewujudkan upaya dalam berhenti merokok tembakau (Shiplo et al., 2017). Sebagian orang yang selesai merokok tembakau mengukuhkan rokok elektrik ini menjadi alternatif untuk selesai merokok tembakau dan sebagian besar dari mereka telah berhasil dalam upaya selesai merokok (Goniewicz et al., 2013), namun perokok elektrik masih cukup khawatir dengan kemungkinan adanya racun yang berbahaya dari rokok tersebut (Etter, 2010). Beberapa riset di Indonesia memperlihatkan hasil identik yaitu sebagian besar pemakai rokok elektrik yaitu perokok aktif konvensional menyampaikan argumen mengenai pemakaian rokok elektrik sebagai solusi dalam upaya selesai merokok. Rokok elektrik bisa menjadi alternatif solusi untuk meminimalisir kebiasaan merokok tembakau (Istiqomah et al., 2016, H. Lee et al., 2016). Riset yang dilaksanakan di Inggris menyatakan perokok tembakau mempercayai rokok elektrik sebagai resiko rendah tentang kebugarannya disbanding dengan rokok tembakau (Dockrell et al., 2013).

Terdapat komposisi kandungan produk yang lebih baik daripada rokok tembakau, rokok elektrik diperkenalkan dengan image yang lebih baik untuk kesehatan. Di samping itu, rokok elektrik juga memproduksi gas berupa uap bukan asap sehingga lebih baik untuk alam tersebut. Sebagai alternatif solusi mengganti rokok berbahan baku tembakau, rokok elektrik berfungsi sebagai alat bagi para perokok tembakau untuk mencoba mengurangi kebiasaan merokok (Damayanti, 2016). Hal yang di dapatkan rokok elektrik mirip dengan rokok tembakau sehingga smoker dapat mengurangi ketergantungan pada rokok berbahan baku termbakau dengan menggunakan rokok elektrik. Vape atau rokok elektrik diyakini mampu mengubah kebiasaan merokok konvensional dengan bahan utama tembakau yang tidak sehat dan berbahaya. Namun menggunakan rokok elektronik belum dapat dikatakan sebagai aktivitas yang baik bagi kesehatan karena hanya mampu untuk mengurangi risiko yang membahayakan dari rokok tembakau. Liquid yang digunakan sebagai bahan baku utama rokok elektrik tidak mengandung tar serta setelah menggunakan rokok elektronik dapat mengurangi keinginan untuk merokok secara konvensional dengan rokok berbahan baku tembakau dan semakin lama 
akan mulai meninggalkan rokok berbahan baku tembakau sebab kehadiran rokok elektrik dengan varian liquid yang beragam juga menjadi daya tertarik bagi rokok elektrik.

Kecenderungan kelompok konsumen atau masyarakat dalam merespon sesuatu sebelum memutuskan untuk melakukan pembelian yang sesungguhnya dikenal dengan istilah purchase intention. Lazimnya seorang konsumen akan melalui sebuah proses evaluasi pemikiran terlebih dulu yang akan mampu membentuk sebuah persepsi sehingga nantinya akan muncul prilaku minat untuk membeli akan suatu produk. Purchase intention akan memunculkan sebuah dorongan internal yang akan terus berkembang di dalam benak konsumen yang semakin lama akan berkembang hingga timbulnya sebuah keinginan yang besar dan muaranya seorang konsumen akan berusaha memenuhi hasratnya dengan melakukan kegiatan pembelian pada sebuah produk yang secara massif selalu berada pada benak konsumen tersebut. Menurut Kotler, P. dan Armstrong (2014) purchase intention merupakan sebuah perwujudan pemikiran secara terencana dan terstruktur seorang konsumen dalam melakukan beberapa transaksi pembelian pada produk tertentu berdasarkan pilihan konsumen terhadap alternatif merek yang ada dalam sesi waktu tertentu. Adapun indikator yang digunakan untuk mengukur purchase intention, yaitu minat transaksional dimana niat untuk membeli kembali, minat eksploratif dimana mencari informasi terkait produk yang akan di beli, minat prefensial dimana niat membeli setelah melihat informasi terkait produk yang akan di beli, dan minat refensial merekomendasikan produk kepada rekan-rekan. Tidak dapat dipungkiri bahwa dampak negatif merokok yang telah di sadari oleh sebagian orang nyantanya belum mampu dalam menekan jumlah prilaku buruk merokok, bahkan justru kencenderungan yang terjadi adalah peningkatan jumlah perokok dari waktu ke waktu, bahkan fakta yang lebih mengerikan dan mengkhawatirkan usia para perokok baru yang tiap tahunnya justru semakin muda (Kurniafitri, 2015). Fenomena merokok ternyata saat ini telah di persepsikan sebagai sebuah gaya hidup baru bahkan kebutuhan bagi beberapa kelompok masyarakat. Kebiasaan merokok saat ini juga di tenggarai sebagai sebuah akibat dari pergaulan sosial, dimana hal ini berarti bahwa prilaku merokok mucul dan tumbuh akibat dari gaya hidup sosial suatu konsumen, dimana dengan melakukan aktivitas merokok tersebut, konsumen merasa dapat diterima oleh lingkungan sosialnya, hingga pada akhirnya konsumen justru kecanduan oleh produk itu sendiri (Lestari et al., 2013).

Beberapa studi di Indonesia menunjukkan penggunaan rokok berbahan baku liquid atau elektrik cenderung mengalami kenaikan yang sangat signifikan. Banyak studi yang menyatakan mengenai kehandalan rokok berbahan baku liquid atau elektrik dalam menyelesaikan permasalahan konsumsi rokok berbahan baku tembakau masih dapat diperdebatkan sebab munculnya temuan yang berbeda-beda mengenai efektivitas rokok berbahan baku liquid atau elektrik dalam menekan pengggunaan rokok berbahan baku tembakau. Di samping itu uji coba pembuktian menunjukan zat nikotin masih banyak ditemukan pada beberapa rokok berbahan baku liquid atau elektrik yang mem posisitioning produknya sebagai produk bebas nikotin (Cho et al., 2011). Peraturan yang dibuat oleh pemerintah Indonesia saat ini yang mengatur tentang rokok elektrik belum menjelaskan mengenai semua faktor, dimana peraturan mengenai kebijakan impor rokok berbahan baku liquid atau rokok elektrik dalam menentukan besaran biaya cukai sebesar 57\% (Peraturan Menteri Keuangan Republik Indonesia No. 146/PMK.010/2017 Tentang Tarif Cukai Tembakau., 2017). Di negara-negara lain yang juga memperbolehkan masyaratnya menggunakan rokok berbahan baku liquid atau elektrik seperti Amerika, melakukan tindaka preverentif dengan membuat kebijakan untuk mengawasi penggunaan rokok berbahan baku liquid atau elektrik seperti regulasi tata cara pemasaran serta batasan minimal usia pengguna yang memenuhi syarat bagi produk rokok berbahan baku liquid atau elektrik (Truth Initiative, 
2018). Dalam studi ini menyatakan bahwa pengguna rokok elektrik di Indonesia cukup tinggi maka Bercermin dari regulasi-regulasi yang di buat negara lain, pemerintah Indonesia dalam hal ini sangat perlu untuk melakukan sebuah kajian serta riset yang terstruktur mengenai rokok berbahan baku liquid atau elektrik yang beredar di seluruh wilayah Indonesia serta melakukan kajian mendalam mengeni efektivitas rokok berbahan baku liquid atau elektrik terhadap upaya menekan laju penggunaan rokok berbahan baku tembakau .

Berkaca pada seluruh fenomena yang ada di atas peneliti termotivasi untuk melakukan sebuah penelitian tentang purchase intention. Purchase intention bisa muncul karena adanya motivasi eksternal, dimana perusahaan melakukan marketing effortnya, sehingga rangsangan yang diberikan ditangkap dengan baik oleh konsumen atau target pasarnya. Setiap stimulus dirancang untuk menumbuhkan minat konsumen dalam melakukan sebuah pembelian pada suatu produk. Pada penelitian ini, variabel yang di duga memberikan pengaruh pada purchase intention adalah lifestyle dan juga social media influencer. Kotler, P. dan Armstrong, 2014 menyatakan bahwa lifestyle adalah sebuah pola atau pattern prilaku seorang manusia yang tercermin dalam aktivitas, minat dan pendapat serta kecenderunganya, lifestyle memberikan capture interaksi seorang konsumen secara menyeluruh dengan lingkungannya. Assael, 2012 berpendapat bahwa suatu lifestyle dipersepsikan sebagai wujud bagaimana seorang konsumen menghabiskan semua waktunya (aktivitas), lalu juga sebagai apa yang sangat berharga bagi konsumen untuk jadikan sebuah pertimbangkan pada lingkungan (minat), serta bagaimana konsumen mempersepsikan dirinya sendiri serta lingkungan sekitarnya (opini). Adapun indikator yang digunakan untuk mengukur lifestyle, yaitu activity dimana produk yang akan digunakan untuk mendukung aktivitas, interest dimana pengguna merasa puas atas produk yang digunakana, dan opinion dimana produk yang digunakan memiliki kualitas (Kotler, P. dan Armstrong, 2014). Keunikan seorang individu dalam memenuhi kebutuhannya sangat dipengaruhi oleh karakteristik lifestyle yaitu prilaku dimana konsumen melakukan aktivitas guna memenuhi segala kebutuhannya seperti hobi, pekerjaan, belanja, hiburan, olahraga serta minat konsumen sesuai dengan kebutuhan terhadap produk yang sangat diinginkan oleh konsumen, serta persepsi konsumen pada suatu produk yang ingin konsumen beli sehingga dapat mempengaruhi perubahan perilakunya. Karakteristik lifestyle menggambarkan sebuah perwujudan mengenai konsumen untuk dipakai perusahaan dalam melakukan strategi iklan guna menghadapi persaingan bisnis yang semakin rumit, berat dan tricky (Boediman, 2017). Lifestyle memainkan peran penting dalam purchase intention konsumen. Beberapa penelitian yang dilakukan oleh (Nora, Liza \& Minarti, 2016), Amri \& Prihandono (2019) menyatakan bahwa lifestyle memiliki pengaruh terhadap purchase intention. Berdasarkan penjelasan diatas dapat dipaparkan sebagai berikut:

\section{$\mathrm{H}_{1}$ : Lifestyle memiliki pengaruh nyata dan positif terhadap purchase intention}

Kehadiran media sosial seperti Facebook, Instagram, Twitter, dan aplikasi sosial lainnya telah mengubah dinamika komunikasi yang digambarkan bersama berdasarkan popularitasnya (Indika \& Jovita, 2017). Seorang influencer media sosial yang kerap kali berinteraksi dengan follower akun media sosial mereka dengan memberikan update informasi terbaru secara kontinyu (Liu et al., 2012). Dalam dunia pemasaran, support dari follower menjadi kunci sukses seorang influencer untuk mendapatkan reputasi baik. Dalam beberapa periode terakhir, seorang influencer media sosial telah memantapkan diri mereka sebagai pendukung potensial dengan menghasilkan berbagai kata kunci dibandingkan dengan strategi pemasaran lainnya (yaitu, dukungan selebriti), dan dianggap sebagai tren pemasaran yang paling hemat biaya dan efektif. Individu yang memiliki hubungan yang kuat dengan seorang influencer akan yakin dengan kredibilitas dari influencer tersebut serta sikap, dan minat pembelian yang muncul dari 
individu tersebut akan cenderung tinggi (Lee, 2017). Seorang Individu akan dapat menangkap pesan dengan cepat jika influencer telah memiliki reputasi yang baik, serta di pandang penting bagi konsumen yang pada akhirnya dapat menumbuhkan purchase intention konsumen terhadap produk yang di tawarkan atau di promosikan oleh influencer tersebut (Glucksman, 2017). Adapun indikator yang digunakan untuk mengukur Social media influencer, yaitu kelompok referensi dimana pedapat dan saran dari seseorang sangat mempengaruhi dalam membeli, keluarga dimana pendapat keluarga mempengaruhi dalam membeli, peran dan status dimana status produk terkait mempengaruhi dalam membeli. Penelitian terdahulu terkait dengan pengaruh social media influencer terhadap purchase intention menunjukkan hasil yang beragam. Beberapa temuan yang dikemukakan oleh Purwanto \& Purwanto, 2019 mengatakan social media influencer memberikan pengaruh pada purchase intention, sedangkan riset yang dilakukan oleh Hermanda et al., 2019 menemukan bahwa social media influencer tidak berpengaruh terhadap purchase intention. Berdasarkan penjelasan diatas dapat dipaparkan sebagai berikut:

$\mathrm{H}_{2}$ : Social media influencer memiliki pengaruh nyata dan positif terhadap purchase intention

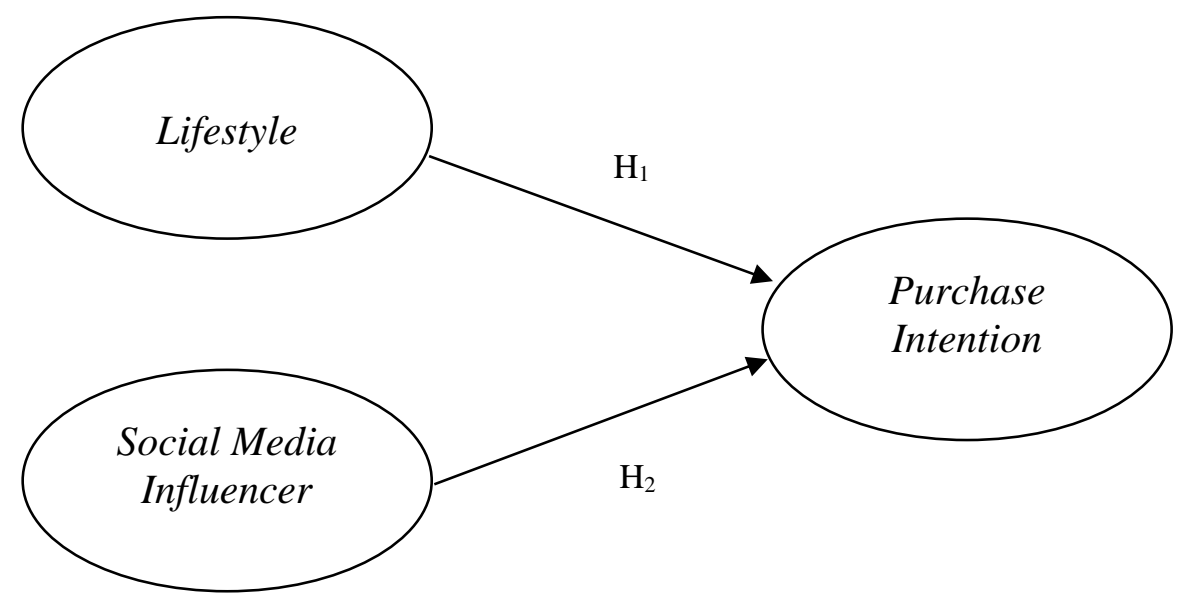

\section{METODE PENELITIAN}

Adapun metode penelitian pada riset ini adalah metode kuantitatif. Alat analisis yang digunakan di dalam penelitian ini adalah analisis regresi linier berganda. Dalam riset ini membahas mengenai faktor lifestyle dan social media influencer dalam mempengaruhi purchase intention smoker menjadi vapor. Proses pengambilan sampel pada penelitian menggunakan teknik sample non probability sampling dengan teknik pengambilan sample dengan metode purposive sampling yaitu teknik pengambilan sample dengan membuat beberapa pertimbangan serta kriteria. Adapun kriteria yang digunakan adalah responden yang berusia 17-25 tahun dan merupakan perokok aktif minimal 1 tahun. Instrument penelitian dalam riset ini diukur menggunakan skala likert dalam mencari besarnya pengaruh variabel independen terhadap variabel dependen. Populasi di dalam penelitian ini adalah generasi Z, yaitu orang yang lahir dalam rentan tahun 1995-2005 dan pernah atau sedang mengkonsumsi rokok tembakau dan berdomisili di provinsi Bali yang jumlahnya tidak dapat teridentifikasi secara pasti. Responden yang didapat dan digunakan pada penelitian ini yaitu sebesar 110 responden dan menggunakan beberapa. 


\section{HASIL DAN PEMBAHASAN}

Hasil analisis deskriptif responden, menunjukkan mayoritas responden yang berjenis kelamin laki - laki ( $\mathrm{n}=87 ; 19 \%)$, sedangkan perempuan $(\mathrm{n}=23 ; 21 \%)$. Responden dengan tingkat pendidikan SMA/Sederajat terbanyak $(n=56 ; 50,9 \%)$, sedangkan responden dengan tingkat pendidikan $(\mathrm{n}=54 ; 49,1 \%)$. Responden yang sudah merokok kurang dari 5 tahun terbanyak dengan jumlah $(\mathrm{n}=78 ; 70,9 \%)$, sedangkan lebih dari 5 tahun berjumlah $(\mathrm{n}=32$; $29,1 \%$ ). Berikut disajikan profil deskriptif responden pada tabel 1 berikut.

Tabel 1. Profil Deskriptif Responden

\begin{tabular}{lll}
\hline Karakteristik & Kategori & \\
\hline Jenis Kelamin & Laki-laki & Perempuan \\
Persentase & 87 & 23 \\
& $79 \%$ & $21 \%$ \\
Tingkat Pendidikan & SMA/Sederajat & S1 s/d S2 \\
Persentase & 56 & 54 \\
& $50,9 \%$ & $49,1 \%$ \\
Lama Menjadi Perokok & $<5$ tahun & $>5$ tahun \\
& 78 & 32 \\
Persentase & $70,9 \%$ & $29,1 \%$ \\
\hline
\end{tabular}

Adapun hasil dari nilai responden terhadap variabel operasional yang diuji dalam penelitian ini yaitu lifestyle, social media influencer dan purchase intention. Penelitian berdasarkan dengan total skor pada tiap indikator pada variabel dibagi dengan jumlah seluruh responden. Dengan demikian hasil dari semua perhitungan tersebut dapat menjelaskan deskripsi nilai dari responden dengan kategori yang dibuat dengan cara mencari nilai interval, rentang nilai dari satu sampai dengan lima yaitu nilai empat, lalu dibagi dengan jumlah kategori yang digunakan yaitu nilai lima, sehingga dapat ditentukan nilai tiap kategori adalah sebesar 0,8 dan untuk pembagian pada tiap kategori disajikan pada tabel 2 yang berada dibawah ini:

Tabel 2. Skor Setiap Indikator Penelitian

\begin{tabular}{llll}
\hline Variabel & Simbol & Skor & Keterangan \\
\hline Lifestyle & LS1 & 0,890 & Baik \\
& LS2 & 0,857 & Baik \\
& LS3 & 0,849 & Baik \\
Social Media Influencer & SMI1 & 0,825 & Baik \\
& SMI2 & 0,823 & Baik \\
& SMI3 & 0,791 & Baik \\
& SMI4 & 0,782 & Baik \\
Purchase Intention & & & \\
& PI1 & 0,838 & Baik \\
& PI2 & 0,902 & Baik \\
& PI3 & 0,872 & Baik \\
& PI4 & 0,825 & Baik
\end{tabular}


Pengujian hipotesis ini dilakukan dengan menggunakan t-statistics, dengan cara memilah untuk melakukan pengujian pengaruh langsung. Pada bagian berikut dapat diuraikan secara berturut-turut hasil pengujian pengaruh secara langsung.

Tabel 3. Hasil Uji Hipotesis

\begin{tabular}{lccc}
\hline & Signifikansi & T-Statistics & Kesimpulan \\
\hline $\begin{array}{l}\text { Lifestyle } \rightarrow \text { Purchase } \\
\text { Intention }\end{array}$ & 0,000 & 6,883 & H1 Diterima \\
$\begin{array}{l}\text { Social Media Influencer } \rightarrow \\
\text { Purchase Intention }\end{array}$ & 0,000 & 6,154 & H2 Diterima \\
\hline
\end{tabular}

Hasil pengujian analisis menunjukkan bahwa lifestyle berpengaruh positif dan signifikan terhadap purchase intention. Hasil ini dilihat dari nilai signifikansi 0,000 dengan nilai t-statistik 6,883. Hasil dari penelitian ini sesuai dengan penelitian yang dilakukan oleh Nora, Liza \& Minarti, 2016, Amri \& Prihandono, 2019. Lifestyle konsumen yang sudah lama ada menunjukkan bagaimana konsumen itu berpikir, hidup, bertindak, dan berperilaku. Ini pada umumnya terlihat dari latar belakang demografis konsumen individu, pengalamannya, situasi atau tindakannya saat ini, karakteristik sosial-ekonomi, dan kecenderungan perilakunya (Bjurling et al., 2017). Segmentasi lifestyle sangat penting mengenai perilaku konsumen karena dampaknya yang besar terhadap purchase intention yang dibuat oleh setiap individu (Hapsari et al., 2017). Lifestyle seseorang dapat dilihat dalam aktivitas, minat, dan pendapatnya. Jika pelaku pasar jeli dalam melihat perubahan lifestyle pasar, maka mereka dapat menyesuaikan gaya penjualannya berdasarkan keinginan pasar yang sesuai dengan lifestyle nya. Konsumen terkadang membeli suatu produk bukan berdasarkan kebutuhan, tetapi lifestyle nya. Motivasi konsumen untuk membeli suatu produk demi mempertahankan atau hanya mengejar lifestyle tertentu. Dari penelitian tersebut, terdapat temuan bahwa dengan menggunakan vape seseorang dapat meningkatkan rasa percaya dirinya dan mereka merasa vape memiliki resiko kesehatan yang lebih kecil daripada merokok.

Selanjutnya, hasil dari analisis data menunjukkan bahwa social media influencer memiliki pengaruh yang positif dan signifikan terhadap purchase intention. Hasil ini dapat dilihat dari nilai signifikansi 0,000 dengan nilai $t$-statistic sebesar 6,154. Penelitian ini sejalan dengan penelitian yang dilakukan oleh (Purwanto \& Purwanto, 2019). Di era internet saat ini di mana-mana telah banyak muncul influencer media sosial yang digunakan sebagai pendukung pihak ketiga yang sangat membantu (Liang \& Dang, 2015). Media sosial menawarkan daya tarik yang unik dibandingkan komunikasi tradisional: kepuasan keinginan, antusias berbagi, mencari nasihat, dan saling berbagi dengan orang lain yang memiliki minat yang sama. Kepercayaan, pendapat, sikap, dan perilaku konsumen dapat dipengaruhi oleh informasi yang disajikan oleh influencer media social (Adiba et al., 2020). Seorang influencer media sosial yang kredibel serta aktif berkomunikasi dengan para audiensnya melalui media digital, dan memiliki daya komunikasi persuasif dalam membentuk citra suatu produk dan berujung pada munculnya purchase intention seseorang (De Veirman et al., 2017). Dari hasil penelitian tersebut, terdapat temuan bahwa semakin banyak perokok yang tertarik mengikuti social media influencer vape akan meningkatkan purchase intention perokok dalam membeli produk vape. Hal ini terlihat dari sikap positif perokok generasi $\mathrm{Z}$ yang sering mengikuti social media influencer produk vape dan berniat membeli produk vape yang ditawarkan. Bagi perokok yang tertarik dengan produk vape yang di tawarkan oleh social media influencer, secara tidak langsung mengubah mereka menjadi vapor. 


\section{SIMPULAN}

Dari hasil penjelasan di atas dapat disimpulkan bahwa : (1) lifestyle berpengaruh positif dan signifikan terhadap purchase intention, artinya lifestyle memiliki pengaruh terhadap purchase intention dimana hal ini berati bahwa dengan menggunakan vape seseorang dapat meningkatkan rasa percaya dirinya dan mereka merasa vape memiliki resiko kesehatan yang lebih kecil daripada merokok, dan (2) social media influencer menunjukkan pengaruh yang positif dan signifikan terhadap purchase intention konsumen, hal ini berarti bahwa semakin banyak perokok yang tertarik mengikuti social media influencer vape akan meningkatkan purchase intention perokok dalam membeli produk vape. Hal ini terlihat dari sikap positif perokok generasi $\mathrm{Z}$ yang sering mengikuti social media influencer produk vape dan berniat membeli produk vape yang ditawarkan. Bagi perokok yang tertarik dengan produk vape yang di tawarkan oleh social media influencer, secara tidak langsung mengubah mereka menjadi vapor.

Penelitian ini juga memiliki kelemahan. Pertama, teknik sampling dalam penelitian ini menggunakan non probability sampling dengan teknik purposive sampling yang didasarkan pada kemudahan dalam mendapatkan responden sehingga menyebabkan keterbatasan generalisasi temuan. Hasil dari penelitian bisa jadi kurang representative karena subjektivitas peneliti dalam pemilihan sampel target penelitian. Penelitian diwaktu yang akan datang dapat menggunakan teknik- teknik sampling yang lainnya agar dapat lebih mewakili populasi yang diteliti. Kedua, penelitian selanjutnya diharapkan dapat menggunakan kelompok berdasarkan pendapatan, berdasarkan kelompok usia atau yang lainnya untuk dapat mengeneralisasi hasil temuan dari penelitian ini.

\section{REFERENSI}

Adiba, S. T., Suroso, A., \& Afif, N. C. (2020). The Effect of Celebrity Endorsement on Brand Image in Determining Purchase Intention. Journal of Accounting, Business and Management (JABM), 27(2), 60. https://doi.org/10.31966/jabminternational.v27i2.700

Amri, S., \& Prihandono, D. (2019). Influence Lifestyle, Consumer Ethnocentrism, Product Quality On Purchase Decision Through Purchase Intention. Management Analysis Journal, 8(1). http://maj.unnes.ac.id

Assael, H. (2012). Assael, Henry. (2012). Consumer Behaviour and Marketing Action, Fifth Edition. Cincinnati Ohio: South-Western College Publishing. 2012.

Bjurling, L., Ekstam, V., Tarnovskaya, V., \& Svensson, P. (2017). Degree project Master's Programme International Marketing and Brand Management Influencer marketing's effect on brand perceptions-A consumer involvement perspective.

Boediman, E. P. (2017). Halal Life Style in Marketing Communication and E-Commerce. International Journal of Pure and Applied Mathematics, 117(15), 931-944. http://www.ijpam.eu

Brown, J., Beard, E. V., Brown, J., Beard, E., Kotz, D., Michie, S., \& West, R. (2014). Realworld effectiveness of e-cigarettes when used to aid smoking cessation: A crosssectional population study Real-world effectiveness of e-cigarettes when used to aid smoking cessation : a cross-sectional population study. May. https://doi.org/10.1111/add.12623

Cho, J. H., Ph, D., Shin, E., Ph, D., Moon, S., \& Ph, D. (2011). Electronic-Cigarette Smoking Experience Among Adolescents. JAH, 49(5), 542-546. https://doi.org/10.1016/j.jadohealth.2011.08.001 
Damayanti, A. (2016). Penggunaan Rokok Elektronik Di Komunitas Personal Vaporizer Surabaya. Jurnal Berkala Epidemiologi, 4(July 2016), 250-261. https://doi.org/10.20473/jbe.v4i2.2016.250

De Veirman, M., Cauberghe, V., \& Hudders, L. (2017). Marketing Through Instagram Influencers: Impact Of Number Of Followers And Product Divergence On Brand Attitude. International Journal of Advertising, 36(5), 798-828.

Dockrell, M., Morrison, R., Bauld, L., \& Mcneill, A. (2013). E-Cigarettes : Prevalence and Attitudes in Great Britain. 15(10), 1737-1744. https://doi.org/10.1093/ntr/ntt057

Eichler, M., Blettner, M., \& Singer, S. (2016). The Use of E-Cigarettes. January 2017. https://doi.org/10.3238/arztebl.2016.0847

Etter, J. . (2010). Electronic cigarettes : a survey of users.

Glucksman, M. (2017). The Rise of Social Media Influencer Marketing on Lifestyle Branding : A Case Study of Lucie Fink I . Introduction II . Literature Review. Elon Journal of Undergraduate Research in Communications, 8(2), 77-87.

Goniewicz, M. L., Lingas, E. O., \& Hajek, P. (2013). Patterns of electronic cigarette use and user beliefs about their safety and benefits : An Internet survey. October 2011, 133-140. https://doi.org/10.1111/j.1465-3362.2012.00512.x

Hapsari, R., Clemes, M. D., \& Dean, D. (2017). The impact of service quality, customer engagement and selected marketing constructs on airline passenger loyalty. International Journal of Quality and Service Sciences, 9(1), 21-40. https://doi.org/10.1108/IJQSS-07-2016-0048

Hermanda, A., Sumarwan, U., \& Tinaprillia, N. (2019). the Effect of Social Media Influencer on Brand Image, Self-Concept, and Purchase Intention. Journal of Consumer Sciences, 4(2), 76-89. https://doi.org/10.29244/jcs.4.2.76-89

Indika, D. R., \& Jovita, C. (2017). Media Sosial Instagram Sebagai Sarana Promosi Untuk Meningkatkan Minat Beli Konsumen. Jurnal Bisnis Terapan, 1(01), 25-32. https://doi.org/10.24123/jbt.v1i01.296

Istiqomah, D. R., Cahyo, K., \& Indraswari, R. (2016). Gaya Hidup Komunitas Rokok Elektrik. 4(April).

Kotler, P. dan Armstrong, G. (2014). Kotler, P. dan Armstrong, Gary. (2014). Principles of Marketing , Fifteenth Edition. Boston: Pearson. 2014.

Kurniafitri, D. (2015). IOM FISIP UR Volume 2 Nomor. 2 Oktober - 2015 1. 2, 1-15.

Lee, H., Lin, H., Seo, D., \& Lohrmann, D. K. (2016). NU SC. Addictive Behaviors. https://doi.org/10.1016/j.addbeh.2016.10.023

Lee, J. S. (2017). The Impact Of Celebrity Endorser Attachment And Endorser-Product Match-Up On Credibility, Attitude, And Purchase Intent. 4, 9-15.

Lestari, V. D., Umamah, M., Pramasari, A. L., \& Dharmawan, Y. (2013). Smoking Effect Video Learning Berbasis Mobile Sebagai Media Penyuluhan Kesehatan Anti Rokok. 3(1), 15-20.

Liang, C.-C., \& Dang, H. T. (2015). Factors Influencing Office-Workers' Purchase Intention though Social Media. International Journal of Customer Relationship Marketing and Management, 6(1), 1-16. https://doi.org/10.4018/ijcrmm.2015010101

Liu, B. F., Jin, Y., Briones, R., \& Kuch, B. (2012). Managing turbulence in the blogosphere: Evaluating the blog-mediated crisis communication model with the American Red Cross. Journal of Public Relations Research, 24(4), 353-370.

https://doi.org/10.1080/1062726X.2012.689901

Nora, Liza \& Minarti, N. S. (2016). The Role of Religiosity, Lifestyle, Attitude as Determinant Purchase Intention. The 2nd International Multidisciplinary Conference 
2016, 135-148.

Peraturan Menteri Keuangan Republik Indonesia No. 146/PMK.010/2017 tentang Tarif Cukai Tembakau., 1 (2017).

Purwanto, A. S. A. C., \& Purwanto, T. (2019). Pengaruh Social Media Influencer Terhadap Purchase Intention Yang Dimediasi Oleh Trustworthiness. Pengaruh Social Media Influencer Terhadap Purchase Intention Yang Dimediasi Oleh Trustworthiness (Studi Pada AkunInstagram @Kulinersby), 1411, 219-231.

Shiplo, S., Czoli, C. D., \& Hammond, D. (2017). E-cigarette use in Canada : prevalence and patterns of use in a regulated market. 1-7. https://doi.org/10.1136/bmjopen-2015007971

Simon, P., Camenga, D., Morean, M., Kong, G., Bold, K. W., Cavallo, D. A., Krishnan-sarin, S., Haven, N., Haven, N., \& Haven, N. (2019). HHS Public Access. 193-198. https://doi.org/10.1016/j.ypmed.2018.04.019.Socioeconomic

Truth Initiative. (2018). E-CIGARETTES tobacco product.

Vardavas, C. I., Filippidis, F. T., \& Agaku, I. T. (2014). Determinants and prevalence of ecigarette use throughout the European Union: a secondary analysis of 26566 youth and adults from 27 Countries. 1-7. https://doi.org/10.1136/tobaccocontrol-2013-051394 